DOI: 10.26693/jmbs05.03.082

UDC 616-008.64: 612.22]:[591.33:599.323.452]=111

Patat Dilara, Nisari Mehtap

\title{
HYPOXIA MODELING TECHNIQUE IN WHOLE RAT EMBRYO CULTURE
}

\author{
Erciyes University, School of Medicine, Department of Anatomy, Kayseri, Turkey \\ dilara.patat@gmail.com \\ mehtaph@erciyes.edu.tr
}

Hypoxia means a decrease in the oxygen level in the body tissues, which causes a decline in the vital activities of the cells. Under lower oxygen concentration, oxidative stress occurs due to free radicals' accumulation in the body tissues. The free radicals are natural products of physiological activity in the body. The free radicals contribute the oxidant-antioxidant levels to keep in balance in the organism. If the free radicals disrupt the oxidant-antioxidant balance, tissue integrity is destroyed. In parallel with, when the oxygen concentration falls below $6 \%$, defects appear in iron metabolism, glucose metabolism, neurogenesis, angiogenesis, and cell proliferation. As conclusion, the cells develop some adaptive responses to survive under hypoxic conditions.

The hypoxia involves both pathophysiological conditions such as; mountain sickness, cancer, obstructive sleep apnea, atherosclerosis, ischemic disease and physiological processes during embryo development. In the early embryonic stage, hypoxia prevents cell proliferation and causes neural cell death. At the same time, craniofacial malformations occur depending on the hypoxia.

The hypoxia comprises four-category as hypoxic, anemic, hypoperfusion, and histotoxic. In this review, particularly emphasized on the embryos exposed to histotoxic hypoxia, which exists in the event of oxidative stress that occurs to the accumulation of free radicals in the culture medium. The embryo culture procedure allows to study early development activities because of maternal metabolism is disabled. In this way, the embryo is examined directly without maternal effects.

In this review, it is discussed how the histotoxic hypoxia is induced due to changes in gas rates in embryo culture medium. This review aims to provide information about the effects of antioxidant substances and plant extracts application to remove hypoxia induced free radicals accumulation ended with oxidative stress on the morphological development of the embryo.

Thus, morphological scoring parameters, yolk sac diameter, head-aft length, somite number are ob- served and many biochemical parameters, histological and molecular biological examinations are made with this technique.

Keywords: Hypoxia, Embryo Culture, Rat, Embryo Development.

\section{INTRODUCTION}

Hypoxia. Oxygen is one of the basic molecules for living aerobic organisms. The main aim of the oxygen is to ensure the formation of ATP (Adenosine Triphosphate) since it is the last electron acceptor in oxidative phosphorylation. ATP is used in many cellular reactions. In other words, the cells must maintain their vital functions. For a cell to maintain its viability under normal oxygen levels, it is necessary to maintain the cellular ATP/ADP (Adenosine Diphosphate) ratio at a high and permanent level. Hypoxia means a decrease in the oxygen level in the body tissues, which causes a decline in the vital activities of the cells. In addition to hypoxia, different terms are used to reduce oxygen levels [1]. One of them is hypoxemia. Hypoxemia is determined as a decrease in oxygen $\left(\mathrm{PaO}_{2}\right.$; oxygen pressure) level in the blood. More specifically, it is oxygen deficiency in arterial blood. Hypoxia particularly occurs during ischemia. Ischemia occurs when a part of the body cannot receive enough blood and oxygen due to a regional decrease or cut in the blood flow. It usually happens due to spasm, compression or obstruction of the arteries; the brain, heart, legs, and intestines may be affected. Its symptoms and treatment vary depending on where it occurs and the affected area of the brain. Ischemia may develop as a result of blockage in vessels by a clot or mechanical agent. Ischemia is not only characterized a restriction of oxygen delivery in blood supply to tissues but also, decrease of nitrogen levels and accumulation of metabolic residues such as $\mathrm{CO}_{2}$, lactic acid and ammonia [2, 3].

Classification of Hypoxia. The first classification of hypoxia was made by Barcroft. This classification is divided into Anoxic, Anemic and Stagnant Hypoxia. Barcroft used the term anoxic in place of the term hypoxic [4]. Later, Peters and Van Slyke were found a 
new category which is histotoxic hypoxia and included this category to old one [5].

a) Hypoxic Hypoxia is the most common form of hypoxia. Hypoxemia is a decline of oxygen pressure in the blood. Hypoventilation (for example, in COPD), changes in ventilation/perfusion ratio, anatomic shunts, diffusion disorders, and high altitude are among the causes of the hypoxic hypoxia. At sea level, the capacity of the oxygen to carry from air in the atmosphere to blood and tissues is higher than at high altitudes [6]. In high altitude areas, even if for instance, a person is healthy at the mountain peak, he/she may be exposed to hypoxia due to lack of oxygen[7].

The effects of exposure to hypoxia (acute or chronic) vary according to cell and tissue types [7]. Most of the energy required for the survival of the organism is obtained by the oxidative phosphorylation. In the case of hypoxia, anaerobic glycolytic (respiration), which produces less energy, is effective. Thus, hypoxia also causes a decrease in adenine dinucleotide (NADH) production and various disorders in the organism. Reactive oxygen species can be formed by xanthine oxidase, mitochondrial electron transport chain, nicotinamide adenine dinucleotide phosphate (NADPH) oxidase and other metabolic pathways ( $\beta$-oxidation). The accumulation of reactive oxygen species primarily damages the brain. It is considered that the brain is the most susceptible organ against hypoxia due to its high necessity for oxygen when the skeletal muscle is the most resistant organ to hypoxia [8].

b) Anemic Hypoxia means the oxygen amount of blood is less than normal $\mathrm{PaO}_{2}$ due to reduced amount of hemoglobin. When hemoglobin value is halved, the amount of $\mathrm{O}_{2}$ transported to the tissues is reduced by half. Anemia and acute massive blood loss are typical causes of anemic hypoxia.

c) Hypoperfusion Hypoxia occurs due to the disruption of the hemodynamics of the circulatory system, in spite of the sufficient amount of oxygen absorbed into the body by the lungs. Shocks and ischemia are characterized by ischemic hypoperfusion hypoxia and heart failure is accompanied by stagnant hypoperfusion hypoxia.

d) Histotoxic Hypoxia can occur from poisoning (cyanide poisoning) that prevents cells from generating energy from oxygen. The amount of oxygen reaching in the tissues is normal, but the tissues cannot use the oxygen due to the various reasons such as inhibition of cellular enzyme systems, cyanide poisoning or decrease in cell membrane permeability on the occasion of the use of certain anesthetics and narcotics [6]. Hypoxia causes oxidative stress in fetal and adult tissues. The cellular damage occurs as a result of excessive production of the reactive oxygen species with oxidative stress [8]. Although it varies from tissue to tissue, the minimum $\mathrm{PaO}_{2}$ required at the tissue level for adequate oxygenation is $20 \mathrm{~mm} \mathrm{Hg}$. Tissue hypoxia is a visible condition in chronic inflammatory diseases. Hypoxia also plays an important role in the formation and function of vascular smooth muscle cells [9].

Local or systemic formation of hypoxia also affects the organism's response to hypoxia. By increasing angiogenesis, dopamine decarboxylase activity, pulmonary ventilation, and erythropoiesis, systemic and tissue-level hypoxia provide more oxygen to the tissues.

At the cellular level, hypoxia causes an increase in vascular endothelial growth factor (VEGF), heat shock proteins (HSP), reactive oxygen and nitrogen species (ROAT), primarily the activity of hypoxiainduced factor (HIF). Moreover, the production of glycolytic enzymes required for glucose transport and anaerobic respiration into the cell increases with hypoxia [10].

Oxidative Stress. Oxidative stress is defined as the deterioration of the balance between the oxidants and antioxidants, that the cell has gained an increase in oxidant direction. The oxidants cause oxidation of various structures in the cell (lipid, protein, carbohydrate) and DNA fragmentation, leading to deterioration of the cell's structural and functional integrity. It consists of reactive oxygen derivatives (ROS), reactive nitrogen derivatives (RNS) and sulfur-based oxidants resulting from the use of molecular oxygen in living organisms that consume oxygen. The reactive oxygen and nitrogen species are the most important oxidant substances as known [11].

Free Radicals. Free radicals are defined as molecules, atoms or ions that have one or more unpaired electrons, which can strongly cause cellular damage in their final orbit. Delocalized electrons make free radicals unstable. Therefore, free radicals try to stable. Since free radicals are reactive, they react with molecules in the environment and cause oxidative damage [12]. The free radicals are also called oxidant molecules. Reactive free radicals cause damage to many biological materials such as DNA, protein, lipid and nucleotide structures [13].

Overproduction of the free radicals causes oxidative damage to biomolecules (proteins, lipids, carbohydrates, and DNA) and can lead to cell damage or death [14]. The harmful effects of reactive oxygen derivatives on the organism are balanced by the antioxidant defense system. During the equilibrium state, cytotoxicity doesn't occur in the organism. When the equilibrium disrupts in the direction of free radicals, this condition causes oxidative stress. In this case, a series of pathological events emerges [15]. 


\section{HYPOXIA EMBRYO CULTURE TECHNIQUE}

Selection and mating of experimental animals.

A Wistar albino (150-250 g) adult female rat is kept in the same cage with an adult Wistar albino male rat during the night (between 17.00 and 08.00) for mating. The animals tend to mate in the middle of the dark period. Therefore, the female rats are separated from the partners at 08.00 a.m. and the vaginal smears are viewed from them. The female rats, a sperm is seen in the vaginal smear, are considered to be half a day pregnant (0.5) and taken to a separate cage and fed for 9 days with a normal diet [16, 17]. All animal experiments were performed according to international principles "of the European Convention for the Protection of vertebrate animals used for experimental and other scientific purposes" (Strasbourg, 18.03.1986)

Preparation of Culture Medium (Serum). Ether anesthesia is applied to 8-10 months old male (300$350 \mathrm{~g}$ ) rats to form the culture medium for embryos growing (Figure 1). Whether the rat is under anesthesia, should be checked with eye reflex. After control, the rat is laid on its back on a flat background. It is fixed with the help of a package tire so that the front and hind legs are stretched [18].
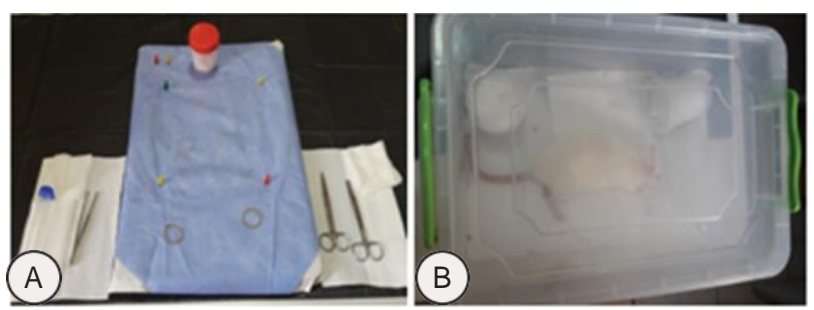

Figure 1. Explantation of embryos; A) general appearance of the materials $B$ ) anesthesia of the rat

The rat's anterior abdominal wall is cleaned with $70 \%$ ethyl alcohol. It is opened with the help of sterile forceps and scissors. The abdominal organs are pushed to the right side of the rat to make the abdominal aorta apparent. A $10 \mathrm{ml}$ sterile injector is injected through the aortic bifurcation to bleed as much blood as possible (approximately $8-10 \mathrm{ml}$ ) despite the amount of blood varies depending on the age and weight of the animal (Figure 2). As soon as the blood is collected, it is centrifuged at $3000 \mathrm{rpm}$ for $5 \mathrm{~min}$ utes. Afterward, the falcon tubes containing the serum can stand for 30 minutes in the water bath is set to $56^{\circ} \mathrm{C}$. Later, the serum is filtrated $0.22 \mu \mathrm{m}$ filter. 100 $\mathrm{IU} / \mathrm{ml}$ penicillin and $100 \mathrm{~g} / \mathrm{ml}$ streptomycin $(10 \mu \mathrm{l}$ penicillin/streptomycin per $1 \mathrm{ml}$ serum) is added depending on the amount of serum. After preparation, the whole serum is placed to $-20^{\circ} \mathrm{C}$. When the serum is to be used, it is kept in a water bath or an incubator at $37^{\circ} \mathrm{C}$ in that it is made ready for use [19].

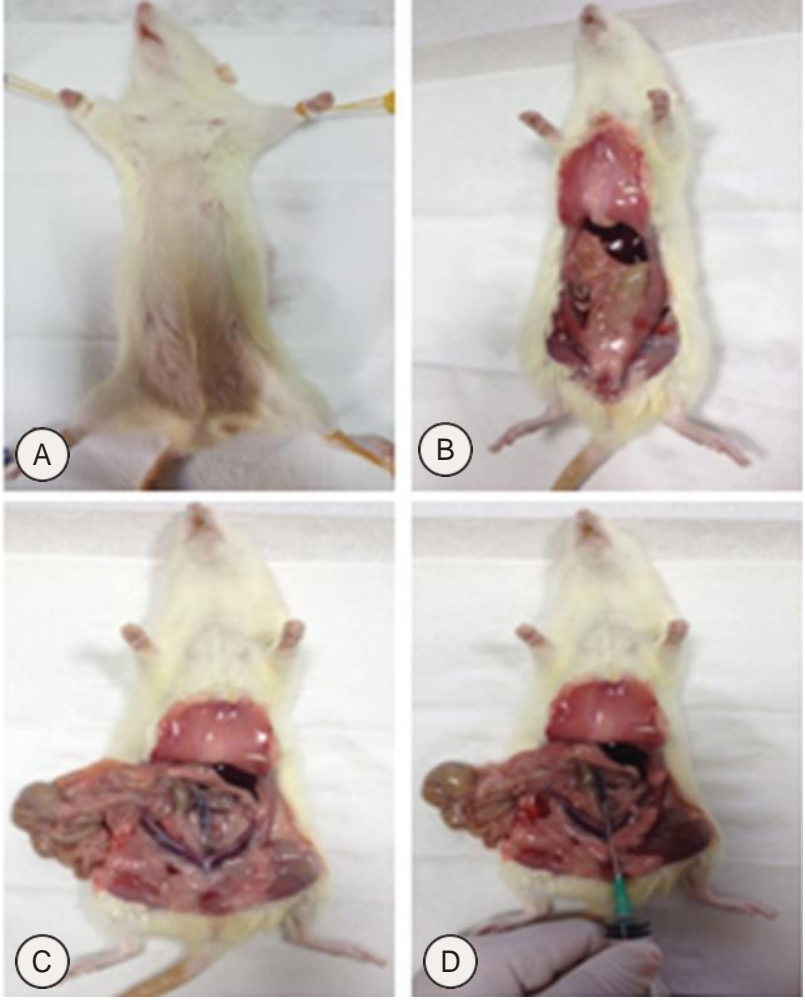

Figure 2. Removing embryos from rats of nine and half day-old pregnant rats

Notes: A) the rat view; B) abdominal wall removal and appearance of organs; C) removal of organs and clarification of abdominal aorta; D) blood collection from bifurcation aorta

Embryos Removal and Culture. Embryos placed in the uterine horn are kept undamaged and transferred into a sterile petri dish with Hanks' solution (HSS's Balanced Salt Solution). Embryos varying between 6 and 16 are separated from each other using sterile scissors and forceps (Figure 3 and Figure 4) [20].

All procedures after this step are carried out in a lamin-air flow cabinet in a semi-sterile environment under a stereomicroscope. A sterile pair of forceps is inserted through the uterine horn to carefully open the uterine muscle along the antimesometrial margin. Decidual tissue is exposed and held on its narrow pole.

A longitudinal incision is made by entering the middle of the other wide pole. The embryo, which is then divided into two equal parts longitudinally and located in the narrow pole of the decidua, is made visible by removing the embryo without damaging it and slowly scraping it from the decidual tissue with forceps. Reichert's membrane, which surrounds the embryo in rodents, prevents the growth of the embryo in the culture medium and removed from the embryonal pole with the help of sterile forceps (Figure 5).

This process is carefully applied to all conceptuses and, at the end of this procedure, the embryos 


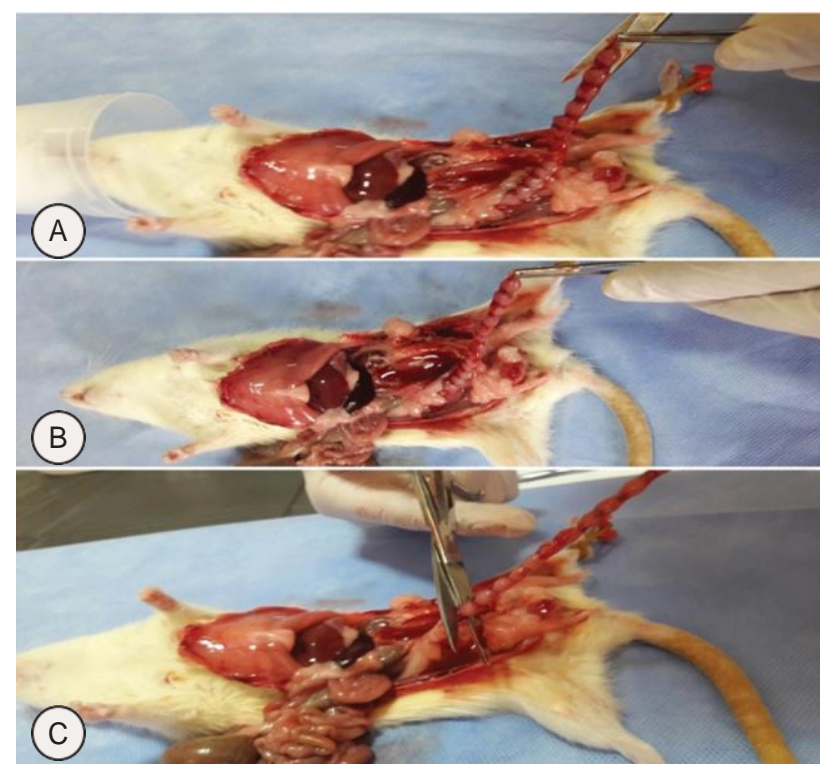

Figure 3. Uterine horn explantation; A-C) removal of uterine horn from rat

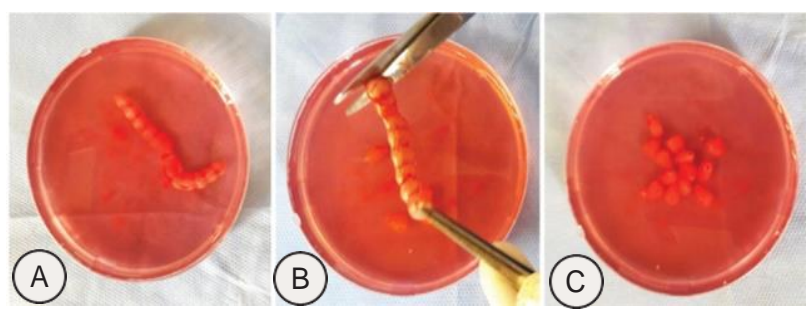

Figure 4. Preliminary preparation steps for explanting embryos; A-C) inclusion of uterine horn into HBSS and separation of embryos from each other

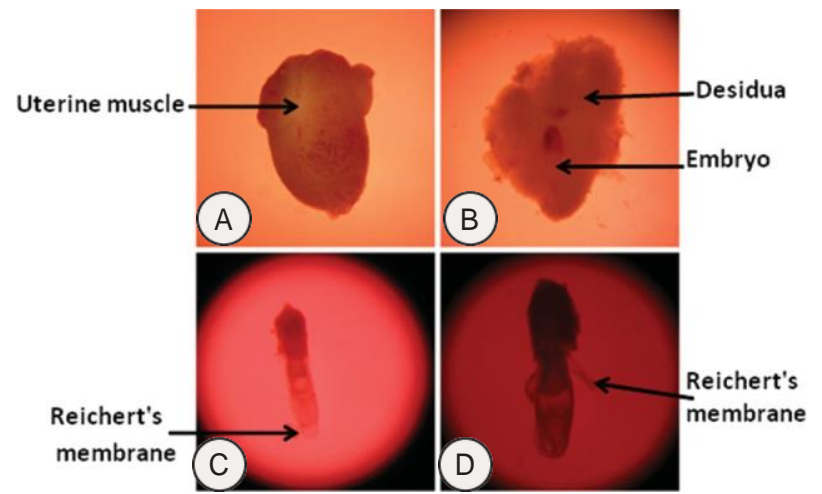

Figure 5. Stages of embryo culture A) uterine muscle view B) decidua view

C) reichert's membrane view D) embryo view

are taken in a small sterile petri dish which consists of HBSS [21].

Culturing Embryos. The embryos that were damaged or had growth deficiency, should not be placed in the culture. Undamaged embryos are placed in groups of 5 with a sterile glass Pasteur pipette into $60 \mathrm{ml}$ sterile transparent glass culture bottles contain- ing $1 \mathrm{ml}$ of serum (1 embryo / $1 \mathrm{ml}$ of serum) for each embryo, in which, a total of $5 \mathrm{ml}$ normal rat serum. Immediately after the embryos are taken into the culture bottles, the gassing procedure is performed with a gas mixture containing $5 \% \mathrm{O}_{2}, 5 \% \mathrm{CO}_{2}, 90 \% \mathrm{~N}_{2}$ (1st gas mixture) for 1 minute. As soon as the gassing process is finished, these bottles are sealed tightly with a sterile cork stopper and placed on a rotating roller incubator at about $30 \mathrm{rpm}(30 \mathrm{rpm} / \mathrm{min})$ in a $37^{\circ}$ C stove.

Twenty-four hours after explant, once again, these bottles are removed from the incubator and the cork stoppers are opened. The gas mixture containing $20 \% \mathrm{O}_{2}, 5 \% \mathrm{CO}_{2}$ and $75 \% \mathrm{~N}_{2}$ (2nd gas mixture) is given for 1 minute. These bottles are closed again and placed in the incubator. Four hours before morphological scoring of the embryos, the gas mixture containing $40 \% \mathrm{O}_{2}, 5 \% \mathrm{CO}_{2}, 55 \% \mathrm{~N}_{2}$ (3rd gas mixture) is given for 1 minute.

Forming Hypoxia in the Embryo Culture. For the hypoxia groups, the embryos are gassed for 1 minute with the gas mixture containing $5 \% \mathrm{O}_{2}, 5 \%$ $\mathrm{CO}_{2}, 90 \% \mathrm{~N}_{2}$ (1st gas mixture) immediately after being taken into the culture bottles. Twenty-four hours after explantation, the gas mixture containing $5 \% \mathrm{O}_{2}$, $5 \% \mathrm{CO}_{2}, 90 \% \mathrm{~N}_{2}$ (1st gas mixture) is given for 1 minute according to the hypoxia gassing rate. Thus, the hypoxic condition is formed in the culture medium. At the end of the procedure, four hours before morphological scoring of the embryos, the gas mixture containing $40 \% \mathrm{O}_{2}, 5 \% \mathrm{CO}_{2}, 55 \% \mathrm{~N}_{2}$ (3rd gas mixture) is given for 1 minute (Table 1) [22].

Table 1 - Gas Rates Used in Culture Medium

\begin{tabular}{l|l}
\hline & \multicolumn{1}{|c}{ GAS RATES } \\
\hline CONTROL & $\begin{array}{l}\text { Gas mixture containing 5\% on first day, 20\% } \\
\text { on second day, 40\% on third day }\end{array}$ \\
\hline HYPOXic & $\begin{array}{l}\text { Gas mixture containing } 5 \% \text { on first day, 5\% } \\
\text { on second day, 40\% on third day }\end{array}$ \\
\hline
\end{tabular}

These embryos kept in culture medium for fortyeight hours are transferred to the sterile Petri dishes containing HBSS (Figure 6-7). These embryos are individually evaluated under the stereomicroscope
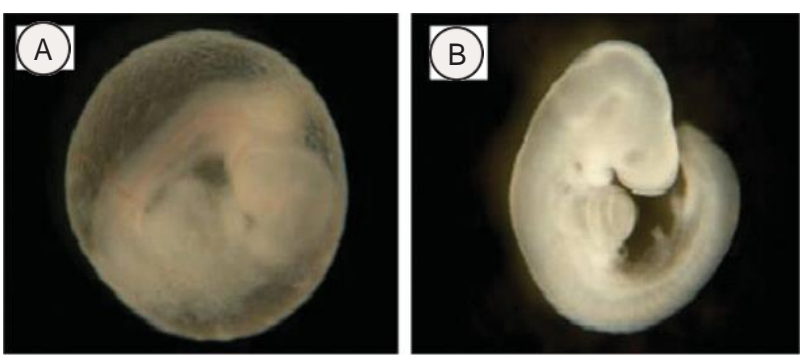

Figure 6. Control Group A) yolk sac view B) embryo view 

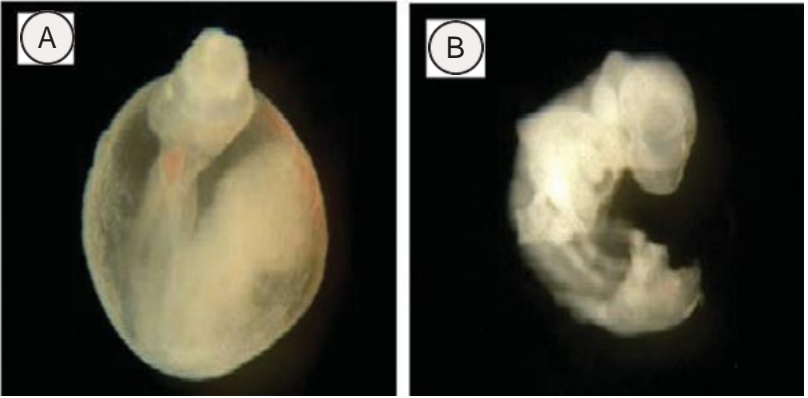

Figure 7. Hypoxic Group A) yolk sac view B) embryo view

according to the morphological scoring method developed by Van Maele-Fabry et al. [23].

To measure the yolk sac diameters and crownrump lengths of these embryos, the eleven and half days $(11,5)$ embryos, put in the sterile petri dish. Before and after removal of the yolk sacs, they are evaluated under the stereomicroscope and photographed.

Since all major organ systems begin to take form after implantation of the embryo into the uterine wall during mammalian development, in vivo studies on the embryo at this stage are quite limited. Because the embryo is implanted into the endometrium during this period, it cannot be followed. It is very small for amnioscopy, radiological methods, or ultrasonography. Physiological differences in maternal metabolism encountered in vivo studies also make it difficult for human results to be interpreted. The reason is that the teratogens may show species-specific changes [5].

Conclusion. It can be concluded that, by using the hypoxic embryo culture model, it is possible to obtain information about the effects of antioxidant substances and the plant extracts on the morphological development of the embryo owing to the free radicals generating oxidative stress.

\section{References}

1. Li J, Bosch-Marce M, Nanayakkara A, Savransky V, Fried SK, Semenza GL, et al. Altered metabolic responses to intermittent hypoxia in mice with partial deficiency of hypoxia-inducible factor-1a. Physiol Genomics. 2006; 25: 450-7. https://doi.org/10.1152/physiolgenomics.00293.2005

2. Zauner A, Daugherty WP, Bullock MR, Warner DS. Brain oxygenation and energy metabolism: part-biological function and pathophysiology. Neurosurgery. 2002; 51(2): 289-301. DOI: 10.1227/01.neu.0000068349.22859.c6

3. Sharp FR, Ran R, Lu A, Tang Y, Strauss KI, Glass T, et al. Hypoxic preconditioning protects against ischemic brain injury. NeuroRx. 2004; 1: 26-35. DOI:10.1602/neurorx.1.1.26

4. Barcroft J. On anoxemia. Lancet. 1920; 2: 485.

5. Peters JP, Van Slyke DD. Quantitative clinical chemistry. American Journal of Clinical Pathology. 1932; 2(6): 492. https://doi.org/10.1093/ajcp/2.6.492

6. Guyton AC. Texbook medical physiology. USA: Elsevier Inc.; 2011. p. 537-9.

7. Welsh DJ, Peacock AJ. Cellular responses to hypoxia in the pulmonary circulation. High Altitude Medicine and Biology. 2013; 14: 111-6. DOI: 10.1089/ham.2013.1016

8. Araneda OF, Tuesta M. Lung Oxidative Damage by Hypoxia. Oxidative Medicine and Cellular Longevity. 2012. Available from: https://www.hindawi.com/journals/omcl/2012/856918/. DOI: 10.1155/2012/856918

9. Hua F, Fengming L, Li Y, Wenchao W, Xiaojing L. Hypoxia stimulates the expression of macrophage migration inhibitory factor in human vascular smooth muscle cells via HIF-1a dependent pathway. BMC Cell Biol. 2010; 11:66.

10. Reyes JG, Farias JG, Olavarrieta-Henriquez S. Madrid E, Parraga M, Zepeda AB, et al. The hypoxic testicle: Physiology and pathophysiology. Oxid Med Cell Longev. 2012; 2012: 929285. DOI: 10.1155/2012/929285

11. Kulkarni AC, Kuppusamy P, Parinandi N. Oxygen, the lead actor in the pathophysiologic drama: Enactment of the trinity of normoxia, hypoxia, and hyperoxia in disease and therapy. Antioxidant and Redox Signaling. 2007; 9: 171730. DOI: 10.1089/ars.2007.1724

12. Cakatay U, Kayali R. Serbest radikal biyokimyasinin tarihsel sürecteki gelisimi. Cerrahpasa Journal of Medicine. 2006; 37: $162-7$.

13. Gracy RW, Talent JM, Kang Y, Conrad CC. Reactive oxygen species: The unavoidable environmental insult? Mutat Res. 1999; 428(1-2): 17-22. DOI: 10.1016/s1383-5742(99)00027-7

14. Fang YZ, Yang S, Wu G. Free radicals, antioxidants, and nutrition. Nutrition. 2002; 18: 872-9. DOI: 10.1016/s08999007(02)00916-4

15. Yen GC, Wu JY. Antioxidant and radical scavenging properties of extracts from Ganoderma tsugae. Food Chem. 1999; 65: 375-9.

16. Nisari M, Ulger H, Unur E, Karaca O, Ertekin T. Effect of interleukin 12 (IL-12) on embryonic development and yolk sac vascularisation. Bratis/ Lek Listy. 2014; 115(9): 532-9. DOI:m10.4149/BLL_2014_103

17. Nisari M, Ulger H. The Embryo Culture Techniques. Journal of Health Sciences. 2010; 19(3): 216-25.

18. Unur E, Ulger H, Ekinci N, Hacıaliogulları M, Ertekin T, Kilic E. Effect of Anti-Basic Fibroblast Growth Factor (AntibFGF) on In Vitro Embryonic Development in Rat. Anat Histol Embryol. 2009; 38(4): 241-5. DOI: 10.1111/j.14390264.2009.00927.x 
19. Ertekin T, Ulger H, Nisari M. Effects of Angiostatin on in vitro Embryonic Rat Development. Kafkas Univ Vet Fak Derg. 2011; 17: 843-7. DOI: 10.9775/kvfd.2011.4637

20. Ulger H, Ozdamar S, Unur E, Pratten M. The Effect of Basic Fibroblast Growth Factor (bFGF) on in vitro Embryonic Growth, Heart and Neural Tube Development in Rat. Kafkas Universitesi Veteriner Fakültesi Dergisi. 2009;673-9.

21. Tekinarslan II, Unur E, Ulger H, Ekinci N, Ertekin T, Hacıalioğulları M, et al. FGF-9'un In Vitro Embriyonik Gelişim Üzerine Etkileri. Balkan Med J. 2011; 28: 18-22. DOI: 10.5174/tutfd.2009.02019.2

22. Torun YA, Ozdemir MA, Ulger H, Hacialiogullari M, Akalin H, Patıroglu T, et al. Erythropoietin improves brain development in short-term hypoxia in rat embryo culture. Brain Dev. 2014 Nov; 36(10): 864-9. DOI: 10.1016/ j.braindev.2014.01.005

23. Van Maele-Fabry G, Delhaise F, Picard JJ. Morphogenesis and Qualification of the Development of Post-implantation Mouse Embryos. Toxicol In Vitro. 1990; 4: 149-56. DOI: 10.1016/0887-2333(90)90037-t

\section{УДК 616-008.64: 612.22]:[591.33:599.323.452]=111 \\ МЕТОДИКА МОДЕЛИРОВАНИЯ ГИПОКСИИ \\ В КУЛЬТУРЕ ЦЕЛЫХ КРЫСИНЫХ ЭМБРИОНОВ \\ Патат Дилара, Нисари Мехтап}

Резюме. Гипоксия означает снижение уровня кислорода в тканях организма, что вызывает снижение жизнедеятельности клеток. При снижении концентрации кислорода возникает окислительный стресс изза накопления свободных радикалов в тканях организма. Свободные радикалы являются естественными продуктами физиологической активности в организме. Они способствуют поддержанию окислительноантиоксидантного баланса в организме. Избыток свободных радикалов нарушает окислительноантиоксидантый баланс, и ткани повреждаются. Параллельно с тем, как концентрация кислорода падает ниже 6\%, возникают нарушения метаболизма железа, метаболизма глюкозы, нейрогенеза, ангиогенеза и пролиферации клеток. Как результат, клетки развивают некоторые адаптивные реакции, чтобы выжить в условиях гипоксии.

Гипоксия возникает как в патологических условиях, таких как горная болезнь, рак, обструктивное апноэ во сне, атеросклероз, ишемическая болезнь, так и при физиологических процессах во время развития эмбриона. На ранней эмбриональной стадии гипоксия предотвращает пролиферацию клеток и вызывает гибель нервных клеток. В то же время появляются черепно-лицевые пороки развития, зависимые от гипоксии.

Выделяют четыре вида гипоксии: гипоксическая, анемическая, гипоперфузионная и гистотоксическая. В данном обзоре особо внимание уделяется зародышам, подверженным гистотоксической гипоксии, которая существует в случае окислительного стресса, возникающего при накоплении свободных радикалов в культуральной среде. Процедура культивирования эмбрионов позволяет изучать их жизнедеятельность на раннем этапе развития в условиях отключения от метаболизма матери. Таким образом, эмбрион исследуется напрямую, без материнского влияния.

В обзоре обсуждается, как возникает гистотоксическая гипоксия в связи с изменениями газового состава в среде культивирования эмбрионов. Целью данного обзора является предоставление информации о влиянии применения антиоксидантных веществ и растительных экстрактов с целью устранения накопления свободных радикалов, вызванного гипоксией и заканчивающегося окислительным стрессом, на морфологическое развитие эмбриона.

Таким образом, с помощью этой методики исследованы морфологические критерии оценки, диаметр желточного мешка, длина голова-хвост, количество сомитов, проводятся исследования многих биохимических параметров, гистологические и молекулярно-биологические исследования.

Ключевые слова: гипоксия, культура эмбрионов, крыса, развитие эмбрионов.

\section{УдК 616-008.64: 612.22]:[591.33:599.323.452]=111 \\ МЕТОДИКА МОДЕЛЮВАННЯ ГІПОКСІї \\ В КУЛЬТУРІ ЦІЛИХ ЕМБРІОНІВ ЩУРІВ \\ Патат Ділара, Нісарі Мехтап}

Резюме. Гіпоксія означає зниження рівня кисню в тканинах організму, що викликає порушення життєдіяльності клітин. При зниженні концентрації кисню виникає окиснювальний стрес через накопичення вільних радикалів в тканинах організму. Вільні радикали є природними продуктами фрізіологічної активності в організмі. Вони сприяють підтримці окиснювально-антиоксидантного балансу в організмі. Коли надлишок вільних радикалів порушує окиснювально-антиоксидантний баланс, тканини пошкоджуються. 
Паралельно з тим, як концентрація кисню падає нижче 6\%, виникають порушення метаболізму заліза, метаболізму глюкози, нейрогенезу, ангіогенезу і проліферації клітин. Як результат, клітини розвивають деякі адаптаційні реакції, щоб вижити в умовах гіпоксії.

Гіпоксія виникає як в патологічних умовах, таких як гірська хвороба, рак, обструктивне апное уві сні, атеросклероз, ішемічна хвороба, так при фізіологічних процесах під час розвитку ембріона. На ранній ембріональній стадії гіпоксія запобігає проліферації клітин і викликає загибель нервових клітин. У той же час з'являються черепно-лицьові пороки розвитку, залежні від гіпоксії.

Гіпоксія буває чотирьох видів: гіпоксична, анемічна, гіпоперфузійна і гістотоксична. У цьому огляді особлива увага приділяється зародкам, підданим гістотоксичній гіпоксії, яка мається в разі окисного стресу, що виникає при накопиченні вільних радикалів у культуральному середовищі. Процедура культивування ембріонів дозволяє вивчати їх життєдіяльність на ранньому етапі розвитку в умовах відключення від метаболізму матері. Таким чином, ембріон досліджується безпосередньо, без материнського впливу.

В огляді обговорюється, як виникає гістотоксична гіпоксія у зв'язку зі змінами газового складу в середовищі культивування ембріонів. Метою даного огляду є надання інформації про вплив застосування антиоксидантних речовин і рослинних екстрактів, з метою усунення накопичення вільних радикалів, яке викликане гіпоксією і призводить до окиснювального стресу, на морфологічний розвиток ембріона.

Таким чином, за допомогою цієї методики досліджені морфологічні критерії оцінки, діаметр жовткового мішка, довжина голова-хвіст, кількість сомітів, проводяться дослідження багатьох біохімічних параметрів, гістологічні та молекулярно-біологічні дослідження.

Ключові слова: гіпоксія, культура ембріонів, щур, розвиток ембріонів.

The authors of this study confirm that the research and publication of the results were not associated with any conflicts regarding commercial or financial relations, relations with organizations and/or individuals who may have been related to the study, and interrelations of coauthors of the article. 